tusion, and the patient never obtained free use of the arm. On March 6th, 1887, I was called to meet his medical attendant, at a distance from Ipswich, to consult about an aneurysm which had formed in the left axilla the size of a large orange. The skin was tense and discoloured. There was distinct pulsation in the tumour and in the brachial artery, but it was very feeble and variable in the radial and ulnar arteries. The whole limb was oedematous. The man suffered great pain, and could only get relief by resting on his elbows and knees. I advised the immediate ligature of the left subclavian artery. The operation was postponed, however, antil March 9 th, 1887, on which day, assisted by three medical friends, I proceeded to ligature the left subclavian in the third part of its course. Having made a free incision, above and parallel to the clavicle, I attempted to reach the vessel in its usual position, but found that in consequence of the great amount of fat, and of the shoulder being pushed up by the very large aneurysm and the vessel drawn down from its normal situation, I was unable to do so. I therefore extended the incision, and applied the ligature from below the clavicle. The pulsation in the aneurysm and in the brachial artery immediately ceased. The patient soon obtained relief from pain, and the axillary tumour gradually diminished. The pulsation in the radial artery was observed by his medical attendant within a fortnight from the operation. The man is now (Dec. 1887) in good health; he has not yet full use of his left arm, but the limb becomes gradually more free, and the circulation continues to improve. Ipswich.

PLACENTA PREVIA AND TWINS IN A PRIMIPARA. BY JaN. D. MACKAY, M.B., C.M.

SoMe time ago I was called to Mrs. M-, a primipara, aged thirty-seven. I found her in bed, and bleeding somewhat freely in gushes. As I had another somewhat urgent case on hand, I administered a quarter-grain morphia pill, and on returning in a few hours found that the hæmorrhage had quite ceased. A few weeks afterwards I was again summoned, and found her bleeding copiously; but she had no pains whatever, and it was now her full time. I again administered a morphia pill, and waited an hour and a half, when, the bleeding still continuing and rather increasing, I proceeded to examine. I had already heard the foetal heart distinctly above the umbilicus, but faintly below. On examination I found the external os slightly patulous, but the internal os barely admitted my finger tip, and $\Upsilon$ could distinctly feel the placenta covering the os and attached round its margin, I administered chloroform with the help of a female neighbour, the only assistant I could get, and proceeded to digical dilatation of the os; and, as soon as it would admit my hand, I felt the head above the placenta, and found that the cord was pulseless. So, seizing both feet with my left hand, I turned and delivered a fairly large, still-born female child. In doing so I had felt in utero what 1 took to be a large clot. But, finding the uterus remained large after delivery, though hard, I examined and found the bag of membranes of another child coming down. I ruptured the membranes, turned, and delivered another female child alive. Shortly afterwards two placentæe came away. There was nothing peculiar in the attachment of the funis in either. Hornby, Lancaster.

\section{SALOL IN CHRONIC RHEUMATISM.}

BP JoHn COChRANE, L.R.C.P. \& L.R.C.S. ED., MEDICAL OFFICER OF THE PARISH OF STRATH, SKYE.

THE treatment of chronic forms of rheumatism being a sort of opprobrium to the profession, I would like to bring under notice the remarkable efficacy of the drug lately introduced into this country for the treatment of different forms of rheumatism. Although one does not like to attach too much importance to its effects in one case alone, still the case I used it in was so severe, and seemingly not amenable to the usual remedies, that I was struck with the speedy improvement on the administration of only a few doses of this drug, called " salol."

Mr. J. R_-., a gentleman of robust physique and temperate habits, was seized with an attack of rheumatism, which attacked first the back of the left thigh, and after- wards settled in the calf of the leg. This pain was most agonising at times, and very of ten prevented sleep at night, although every means possible was adopted to assuage it. Even repeated hypodermic injections of morphia, the internal administration of chloral, bromide of potassium, \&c., and the use of numerous liniments, were of no avail. This sort of thing continued through last spring and summer with more or less abatement, and at last I advised him to go to Strathpeffer Wells, where he was also under the care of one of the local medical men. When he went there at first the old symptoms returned with redoubled severity, but at last were gradually reduced under treatment. He then returned home here, and has had occasional severe twinges of pain more or less up till the time I put him on the salol. I was not very sanguine about it, however, but was agreeably surprised to find it had relieved him at once. He is quite pleased to think that he is so well as to be able to go about in the most severe weather, such as we have been experiencing in Skye. He says he has now no pain at all since taking it, and never felt so well in his life. He had an attack of lumbago several years ago, but was never laid up with any other illness. This attack was brought on through sitting on the wet grass one day in the beginning of spring, when the air was damp and cold.

Skye.

\section{A}

$$
\text { of }
$$

\section{HOSPITAL PRACTICE, BRITISH AND FOREIGN.}

Nulla autem est alia pro certo noscendi via, nisi quamplurimas et morborum et dissectionum historias, tum aliorum tum proprias collectas habere, et inter se comparare.-MoRGAGNI De Sed. et Caus. Morb., lib. iv. Procemium.

\section{ST. BARTHOLOMEW'S HOSPITAL.}

ACUTE INTESTINAL OBSTRUCTION (STRANGULATED OBTURATOR HERNIA?); LAPAROTOMY;

$$
\text { RECOVERY. }
$$

(Under the care of Mr. Morrant BakER.)

TAKING all the circumstances of the following case into consideration, it seems most likely that it was one of strangulated obturator hernia, although its nature was not suspected before operation. The notion is encouraged by the fact that other herniæ were present. However this may be, the point of greatest interest lies in the finding the obstructed bowel, and relieving it by the performance of the operation. The case was obviously a hopeless on $\theta$ without operative interference, and can therefore be added to the list of those, unfortunately in a minority, in which the operation of laparotomy for acute intestinal obstruction of obscure nature is the means of directly saving life. For the notes of the case we are indebted to Mr. Robert Cross, late house-surgeon.

W. D- aged forty-five, warehouseman, was admitted on the afternoon of April $30 \mathrm{th}, 1887$. The patient, a strong, muscular man, stated that he had been ruptured for many years on both sides, and had worn a truss for about the last eight years. The herniæe often came down, but he had never had any trouble in reducing them. He had also a small reducible umbilical bernia. The patient was quite woll up to the morning of April $25 \mathrm{th}$ (five days before admission), when, after working for about half an hour, he was suddenly seized with severe abdominal pain, referred to the umbilicus, and thence downwards to the right side of the pubes. The pain was of a dragging character, and thinking that it might be due to the hernia on that side not being quite all reduced, he lay on his back and readjusted his truss, but without relief. The pain continued all that day and the next, but be still remained at work, and vomited a little on both days. On April 27th the pain was worse, and the romiting more frequent. On the 28 th and 29 th the pain and vomiting had increased. On the 30 th (day of admission) the patient was much worse and very weak, the pain being intense, and he had vomited at least twenty times in the twenty-four hours.

State on admission.-The patient is much collapsed, with 